\title{
Resurrection of Pomphorhynchus tereticollis (Rudolphi, 1809) (Acanthocephala: Pomphorhynchidae) based on new morphological and molecular data
}

\author{
M. ŠPAKULOVÁ*, M.-J. PERROT-MINNOT ${ }^{*}{ }^{1}$, B. NEUHAUS ${ }^{2}$
}

\begin{abstract}
Institute of Parasitology SAS, Hlinkova 3, 04001 Košice, Slovak Republic, E-mail: spakulma@saske.sk; ${ }^{1}$ Université de Bourgogne, Equipe Ecologie Évolutive, UMR CNRS 5561 Biogéosciences, 6 Blvd Gabriel, 21000 Dijon, France; ${ }^{2}$ Museum für Naturkunde, Leibniz-Institut für Evolutions- und Biodiversitätsforschung an der Humboldt-Universität zu Berlin, Invalidenstrasse 43, D-10115 Berlin, Germany
\end{abstract}

\begin{abstract}
Summary
Pomphorhynchus tereticollis (Rudolphi, 1809) is here redescribed on the basis of Rudolphi's material, deposited in the Museum für Naturkunde Berlin, and on acanthocephalans recently collected from the type host Platichthys flessus (L.) and the region embodying the type locality. Out of the paratypes of $P$. tereticollis, the lectotype and paralectotypes have been designated. Their morphology fits well with that of newly collected material of $P$. tereticollis dissected from the type fish host from the Baltic coast near Stralsund. The resurrection of $P$. tereticollis, previously considered a synonym of Pomphorhynchus laevis (Zoega in Müller, 1779), is supported by several morphological features distinguishing the two Pomphorhynchus species: 1 . The basal parts of the proboscis hooks located on the posterior proboscis half possess proximal projections in $P$. tereticollis but not in P. laevis. This shape of the hook bases is clearly visible only in unfixed fresh worms; 2 . The last hooks are situated at the anterior part of the bulbus or rarely at the posterior-most end of the proboscis in P. tereticollis, while they lie anterior to the end of the proboscis in P. laevis; 3 . The proboscis hooks No. 5 or 6 are markedly stout (robust) and clearly distinct in comparison with the surrounding hooks in P. tereticollis, while less robust and more similar to the hooks in $P$. laevis. In addition, genetic divergence between $P$. tereticollis and $P$. laevis based on ITS1, ITS2 and COI sequencing supports the existence of two distinct species and reveals that some isolates previously identified as $P$. laevis were actually $P$. tereticollis. Previous and present morphological and genetic data show that both Pomphorhynchus species occur in freshwaters throughout Europe and may infect the same fish hosts, such as chub and barbel, and also several species of isopods (Gammaridae). This study also provides morphological evidence that Pomphorhynchus intermedius Engelbrecht, 1957 is a synonym of $P$. tereticollis, because
\end{abstract}

\footnotetext{
* Both authors contributed to the work equally.
}

the only discrimination character of the former species, the "existing but small proximal projections of basal parts of the proboscis hooks located on the posterior proboscis half" are present also in $P$. tereticollis.

Keywords: lectotype; paralectotype; redescription; Pomphorhynchus laevis; genetic differentiation

\section{Introduction}

Acanthocephalans are interesting models to study the ecology and evolution of parasites with complex life cycle, in particular to address important issues such as specificity, parasite-induced behavioural and physiological changes in their hosts, and ecotoxicology (Kennedy, 2006). A number of ecological, behavioural and biochemical studies have been carried out using the common Palaearctic species Pomphorhynchus laevis (Zoega in Müller, 1776) as a model, because it exhibits a broad geographical distribution and range of fish definitive hosts. However, a rather high morphological and physiological intraspecific variability has been reported in this species both in the British Islands (Kennedy et al., 1978; Kennedy, 1984; Brown, 1987; Guillén-Hernández \& Whitfield, 2001; O’Mahony et al., 2004) and in continental Europe (Dudiňák \& Šnábel, 2001; Chibani et al., 2004; Perrot-Minnot, 2004).

These data have been then supplemented by the information on genetic characters, which indicated the existence of a cryptic species within the $P$. laevis species complex, notwithstanding the final fish host and/or geographic origin (Dudiňák \& Šnábel, 2001; Králová-Hromadová et al., 2003; Perrot-Minnot, 2004, Bombarová et al., 2007). Genetic studies revealed a high level of sequence divergence between two clusters of samples of acanthocephalans inferred from sequences of internal transcribed spacers 1 and 2 of nuclear rDNA and the mitochondrial cytochrome c oxidase subunit 1 gene (11.8\% and $20 \%$, respectively) 


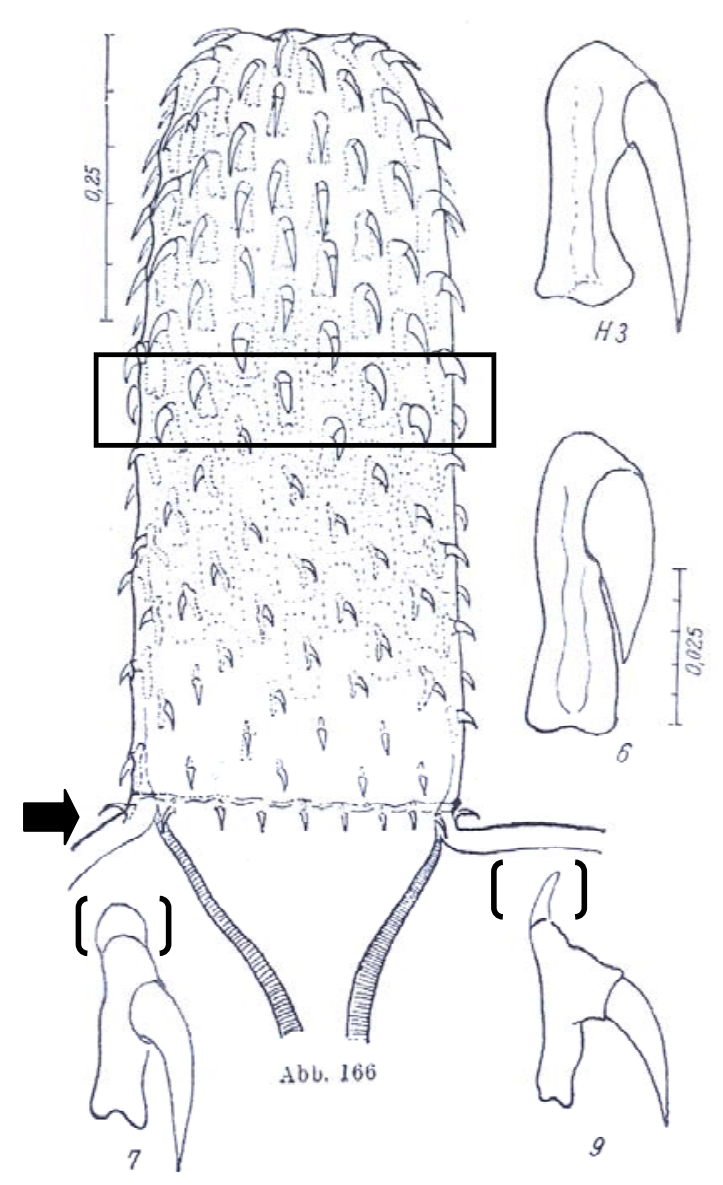

Fig. 1. Drawings of proboscis and selected hooks of Pomphorhynchus tereticollis (original by Meyer, 1932-1933). Rectangle indicates the proboscis area with the stoutest hooks Nos 5 and 6; arrow indicates the last hooks located on the bulbus; brackets indicate the proximal parts of the base of $7^{\text {th }}$ and $9^{\text {th }}$ hooks armed with a projection.

(Králová-Hromadová et al., 2003; Perrot-Minnot, 2004). The existence of two cryptic Pomphorhynchus species was further supported by a karyological study (Bombarová et al., 2007).

It has been suggested that one species corresponds to $P$. laevis, whereas the other may be conspecific with the previously described European species Pomphorhynchus tereticollis (Rudolphi, 1809) (Perrot-Minnot, 2004; Bombarová et al., 2007). However, these observations were awaiting a formal redescription of $P$. tereticollis, which was considered to be a synonym of $P$. laevis (Amin et al., 2003). In addition, Pomphorhynchus intermedius Engelbrecht, 1957, another synonym of P. laevis (Amin et al., 2003), can occur across the ecological and geographical range of $P$. laevis.

Pomphorhynchus tereticollis was described by Rudolphi (1809, 1819) as Echinorhynchus tereticollis from Platichthys flessus (L.) (syn. Pleuronectes flessus) from Baltic coast at the vicinity of Greifswald, Germany, but the author mentioned it also from other freshwater fishes. Meyer (1932 - 1933) transferred the species to Pomphorhynchus Monticelli, 1905 and reported that $P$. tereticollis from the
Baltic Pleuronectes platessa L. was morphologically very close to freshwater $P$. laevis, differing in less conspicuous size difference between long anterior and short posterior proboscis hooks. The other features typical for $P$. tereticollis are apparent from the original drawings of Meyer (1932 - 1933) (Figs 1, 2). The most marked difference is the shape of the basal parts of the proboscis hooks located in the posterior proboscis half. These hook bases possess proximal projections in P. tereticollis (Fig. 1), which are not present in $P$. laevis (Fig. 2), as confirmed also by Petrochenko (1956). Moreover, the last hooks are localised at the anterior part of the bulbus or at the posterior-most end of the proboscis in P. tereticollis (Fig. 1), but more anteriorly in P. laevis (Fig. 2; Petrochenko, 1956). The stoutest (robust) hook in the middle of the proboscis, presented in both species, seemed to be more distinct from surrounding hooks in $P$. tereticollis than in P. laevis.

Later, Engelbrecht (1957) studied Pomphorhynchus specimens from the Baltic flounders $P$. flessus and $P$. platessa and reported a rather broad morphological variability in the shape of the hook bases. He divided flounder parasites into two forms, namely $P$. laevis f. tereticollis possessing hook bases "armed", with prominent proximal projections, and the new taxon $P$. laevis f. intermedius, having smaller projections. Golvan (1969) erected both forms to the species level as $P$. tereticollis and $P$. intermedius. Since the shape of the hook bases in Pomphorhynchus spp. is visible exclusively in living worms and this character disappears in fixed material, it was not considered in later studies. Overall similarity of parasites from flounders and other fish hosts throughout Europe with common P. laevis caused that solely this specis was considered as valid (Amin et al., 2003).

Formally, a thorough morphological description of $P$. tereticollis has never been published, even though the original Rudolphi's material of $P$. tereticollis exists (Hartwich et al., 1998). The present paper redescribes the type material

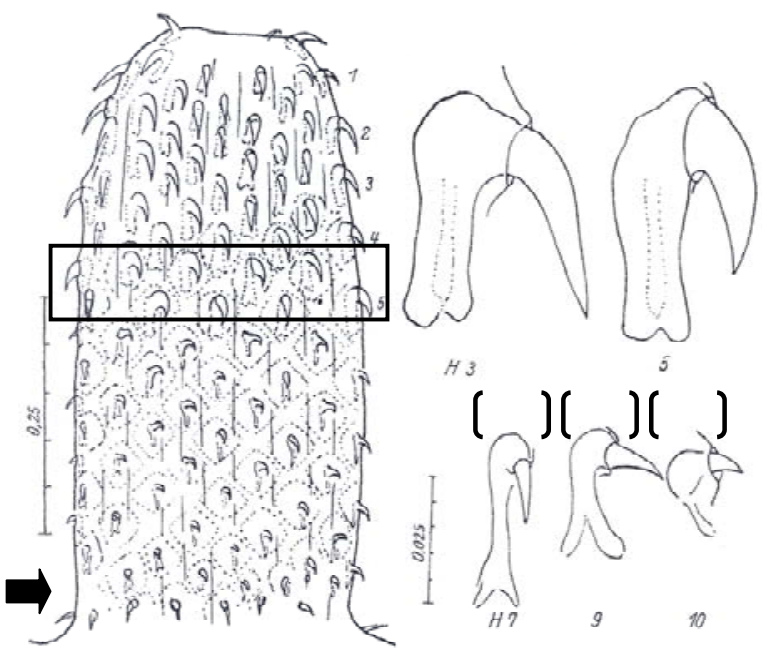

Fig. 2. Drawings of proboscis and selected hooks of Pomphorhynchus laevis (original by Meyer, 1932-1933). Rectangle indicates the proboscis area with less stout hooks Nos 5 and 6; arrow indicates the last hooks located on proboscis; brackets indicate the proximal parts of the base of $7^{\text {th }}, 9^{\text {th }}$ and $10^{\text {th }}$ hooks devoid projections. 
Table 1. ITS and COI GenBank accession numbers of Pomphorhynchus tereticollis and Pomphorhynchus laevis.

Specimens of $P$. tereticollis misidentified as $P$. laevis are labelled with an asterisk. Hosts and localities of collection are also given, with abbreviations used in Fig. 6. New sequences (this study) are in bold.

\begin{tabular}{|c|c|c|c|c|}
\hline & Locality & Host & ITS & $\mathrm{COI}$ \\
\hline \multicolumn{5}{|l|}{ P. tereticollis } \\
\hline Germany & Stralsund (ST), Baltic Sea & Platichthys flessus (Pf) & JF06705 & $\begin{array}{c}\text { JF706706, JN695505 - } \\
\text { JN695508 }\end{array}$ \\
\hline \multicolumn{5}{|l|}{ P. laevis } \\
\hline \multirow[t]{3}{*}{ France * } & Ouche River (OU) & Gammarus pulex (Gp) & AY424670 & AY423351 \\
\hline & Tille (MA), Borne (BO) & Gammarus pulex & - & AY423352, AY423353, \\
\hline & Vingeanne (VI) Rivers & Leuciscus cephalus (Lc) & - & JN695504 \\
\hline \multirow[t]{2}{*}{ Slovakia * } & Olšava River (OL) & Leuciscus cephalus & AY135413 & \\
\hline & Small Vihorlat Lake (VL) & Phoxinus phoxinus (Pp) & AY135414 & - \\
\hline Denmark * & Northern Øresund (NO) & Platichthys flessus & - & AY218096 \\
\hline \multirow[t]{3}{*}{ France } & Ouche River & Leuciscus cephalus & & AY423348 \\
\hline & Ouche River & Gammarus pulex & AY424669 & AY423348 \\
\hline & Tille River & Gammarus roeseli $(\mathrm{Gr})$ & & EF051062 - EF051065 \\
\hline \multirow[t]{2}{*}{ Czech Republic } & Rokytná River (RO) & Leuciscus cephalus & AY135415 & $\frac{-}{-}$ \\
\hline & & Gammarus roeseli & & EF051070, EF051071 \\
\hline \multirow[t]{2}{*}{ Hungary } & Tapolca River (TA) & Gammarus roeseli & - & EF051066 - EF051069 \\
\hline & & & & AY423349, AY423350 \\
\hline
\end{tabular}

and morphological and molecular data on newly collected flounder acanthocephalans from the Baltic region are provided. This makes it possible to resurrect $P$. tereticollis, which occurs throughout Europe more widely than it has been supposed.

\section{Materials and methods}

Materials and morphology

Original Rudolphi's material of $P$. tereticollis from $P$. flessus from the Baltic coast near Greifswald, deposited in the helminthological collection of the Museum für Naturkunde Berlin (acronym ZMB), was studied during a

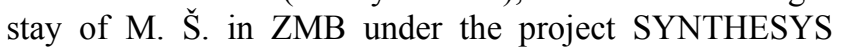
(DE-TAF-2337). In a vial No. ZMB Entozoa 1226, 5 males and 3 females out of 56 syntypes were freely available, whereas the remaining 48 acanthocephalans were destroyed or burrowed into the fish gut wall by their proximal body part. Eight specimens were cleared in glycerin-ethanol for a short time, drawn and measured with the help of the light microscope Zeiss Axioskop 50 equipped with a drawing tube.

Fresh Pomphorhynchus material was obtained from 15 flounders $P$. flessus, which were purchased alive from a fisherman in Barhöft port at the Baltic coast, Germany, in October 2006. Fish were caught in the Baltic Sea area called Plantagenet-Ground, which is connected with the type locality in Greifswalder Bodden via Strela Sund near Stralsund, Germany (distance about $50 \mathrm{~km}$ ). The fish were 335 - $490 \mathrm{~mm}$ long and were all infected with Pomphorhynchus parasites (below mentioned as Stralsund samples), with the intensity of infection $1-30$ (mean $=11.7)$. Parasites were located in the posterior part of the fish gut.

Out of 175 acanthocephalans obtained, 30 unfixed females and 30 males were used for drawings of entire proboscis hooks. Afterwards, the material was divided into two parts and fixed either with $4 \%$ formalin for morphology and with $99 \%$ ethanol for molecular analysis, respectively. A total of 17 males ( $1-5$ worms from 9 flounder hosts) and 14 females $(1-2$ worms from 9 fish) were used for measurements and drawings after clearing in glycerin-ethanol. Measurements of proboscis hooks represent the length and width of the outer visible hook part as used by Wayland (2010).

\section{Molecular characterization}

Pomphorhynchus tereticollis individual samples from the type host ( $P$. flessus) and the type region (Stralsund locality) were compared with previously published sequences of freshwater P. laevis (Králová-Hromadová et al., 2003; Giribet et al., 2004; Perrot-Minnot, 2004; Moret et al., 2007) (Table 1). DNA extraction, amplification and sequencing of the ITS $1+5.8 \mathrm{~S}+\mathrm{ITS} 2$ rDNA region and the COI gene were done following Perrot-Minnot (2004). Sequences were aligned using ClustalW procedure in BioEdit editor (Hall, 1999), and the rate of genetic divergence between Stralsund isolates and sequences of $P$. laevis available in GenBank were calculated. Two types of phylogenetic analyses were performed using MEGA v.5.04 with 1000 bootstrap replications: a distance-based Neighbor-Joining (NJ) analysis and Maximum Likelihood (ML) analysis.

\section{Results}

\section{Pomphorhynchus tereticollis (Rudolphi, 1809)}

\section{Redescription}

Based on measurements of 5 males and 3 females, all juvenile, from ZMB Entozoa 1226 (Fig. 3A - C) and freshly collected material of 17 males and 14 females, all adult (Fig. $4 \mathrm{~A}-\mathrm{E})$. Measurements are in $\mu \mathrm{m}$ unless otherwise stated. 


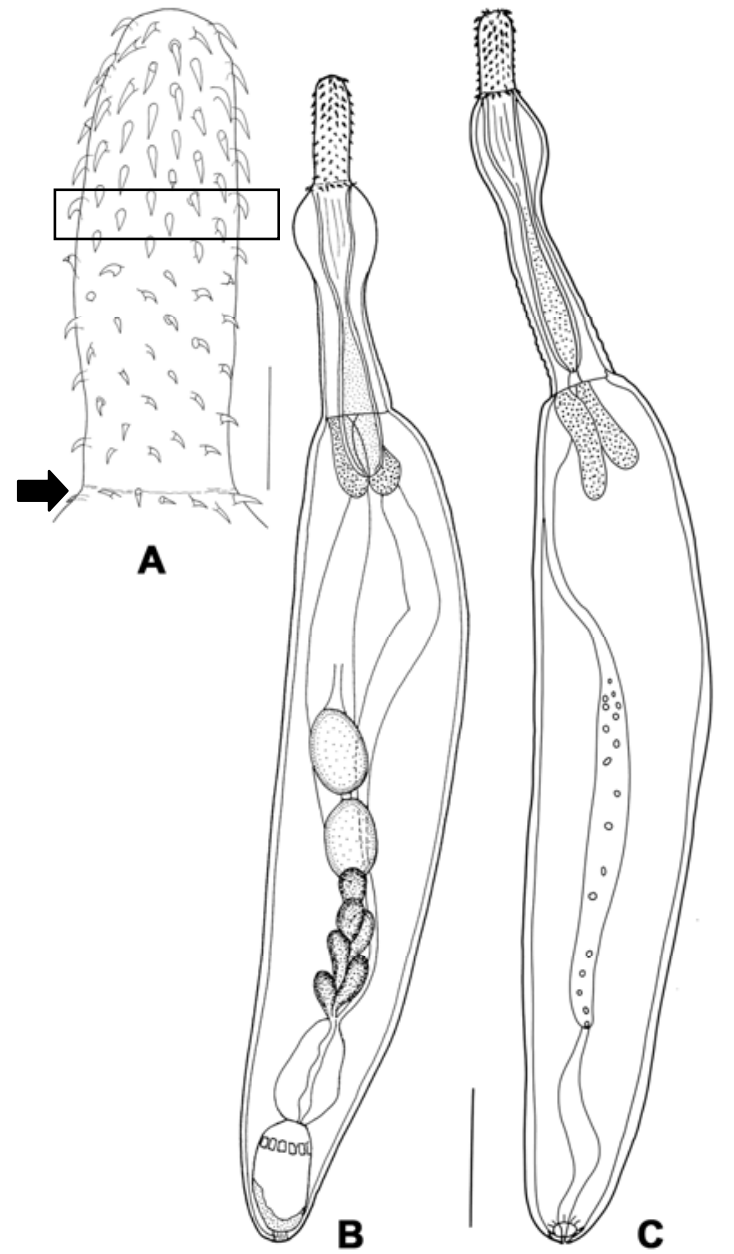

Fig. 3. Pomphorhynchus tereticollis. Male lectotype (A, B; ZMB Vermes Entozoa 1226) and female paralectotype (C; ZMB Vermes Entozoa 7500a) from Rudolphi's original material. Bar $=200 \mu \mathrm{m}$ in (A) and $1 \mathrm{~mm}$ in $(\mathrm{B}, \mathrm{C})$. Rectangle indicates the proboscis area with the stoutest hooks Nos 5 and 6; arrow indicates the last hooks located on the bulbus (A).

General. Pomphorhynchidae, with characters of genus. Trunk elongated (Figs 3B, C, 4C, D). Neck of moderate length, somewhat tapered, broader at base, with prominent distal bulb. Proboscis cylindrical, with 13-18 longitudinal rows of $8-12$ hooks each (Figs 3A, 4A, B, 5A). Hooks directed posteriorly; last hooks situated on proximal end of bulb or posterior-most margin of proboscis, directed oblique (Figs 3A, 5A). First four to five hooks (from anterior end) longest; fifth or sixth hooks stoutest. Hooks posterior to fifth or sixth hook remarkably shortest (Figs 3A, $4 \mathrm{~A}, \mathrm{~B}, 5 \mathrm{~A})$. Hook roots, visible only in fresh unfixed material, without proximal protrusions (Fig. 4A) or exceptionally with small projections (Fig. 4B) in anterior hooks including the stoutest one. Hook bases at posterior half of proboscis with marked proximal projections (Figs 4A, B, 5C). Proboscis receptacle swollen posteriorly, in some specimens extending into body cavity (Fig. 3B). Muscular wall of receptacle incomplete posteriorly. Lemnisci subequal, slightly broader posteriorly, not extending to anterior testis (Figs 3B, 4C).
Male: based on 5 juvenile specimens - lectotype and 4 paralectotypes (Fig. 3A, B) and 17 adult specimens (Fig. $4 \mathrm{~A}, \mathrm{C}$, data in parentheses).

Body length $7.4-9.4(10.7-15.9)$ mm. Trunk $5.3-6.4$ (7.4 - 11.4) mm long, $1.1-1.6(1.4-2.1) \mathrm{mm}$ wide. Neck $0.9-1.4(1.2-1.9) \mathrm{mm}$ long, $300-400(250-500)$ wide just posterior to bulb and $420-530(450-800)$ wide close to trunk. Bulb ovoid, round or ellipsoid, $600-950$ (5201470) long and $520-650(640-1540)$ wide. Proboscis $440-790(590-880) \times 210-300(270-360)$ wide in middle, with $13-14(14-17)$ longitudinal rows of $10-$ $11(8-12)$ hooks each. Proboscis hook length and width from anterior: [First hook] $50-53 / 13-15(30-55 / 8-$ $15) ;$ [ 3 - 4 subsequent hooks] $40-55 / 13-17(40-62 / 9-$ 17); [stoutest fifth or sixth hook] $35-45 / 17-22(36-$ $52 / 15-22)$; [ $3-5$ hooks posterior to stoutest hook] $26-$ $31 / 7-10(21-48 / 7-13)$; [last hook directed oblique] 22 $-31 / 7-9(20-40 / 6-12)$. Proboscis receptacle $1.9-2.2$ $(1.5-3.1) \mathrm{mm} \times 210-290(200-360)$ wide at posterior end. Two lemnisci $570-650(500 / 555-1270 / 1325) \times 150$ - $250(90 / 140$ - 540/570). Testes two or exceptionally single (in one paralectotype from five and three adult males from 17), pre-postequatorial, subequal, ovoid, usually contiguous, occasionally detached up to 440 . Anterior testis $540-635(540-985) \times 330-390(380-$ $750)$, posterior testis $515-620(570-1020) \times 330-370$ $(360-600)$, in case of single testis $960 \times 500(640-1520$ $\times 570-650)$. Six elongate-pyriform cement glands with cylindrical core, $240-380(180-750) \times 130-170(125-$ 540 ). In 2 of 17 adult males (other than males with a single testis), two larger glands $(680-1160 \times 460-540)$ and two smaller glands $(360-480 \times 360-400)$ (Fig. 4C). Saefftigen's pouch just posterior to cement glands, $800-$ $925(800-1430) \times 350-410(320-640)$. Copulatory bursa $(625-1130 \times 320-570)$ when retracted and $(412-$ $805 \times 570-720)$ when protruded (Fig. 4C). Fully everted bursa in single male $(90 \times 50)$. Gonopore terminal.

Female: based on 3 juvenile female paralectotypes (Fig. 3C) and 14 egg-bearing females (Fig. 4B, D, E, data in parentheses).

Body length $7.8-9.3(15.4-21.0)$ mm. Trunk $4.5-6.3$ (7.6 - 16.5) mm long, $1.2-1.7(1.2-2.4) \mathrm{mm}$ wide. Neck $1.3-1.9(1.4-2.4) \mathrm{mm}$ long, $270-290(300-380)$ wide just posterior to bulb and $450-540(450-540)$ wide close to trunk. Bulb ovoid, round or ellipsoid, $840(700-1570)$ long and $530-750(930-1630)$ wide. Proboscis $530-$ $630(630-930) \times 215-330(250-380)$ wide in middle, with $15-17(15-18)$ longitudinal rows of $11-12(9-$ 12) hooks each. Proboscis hook length/width from anterior: [First hook] $45-50 / 12-13(30-56 / 6-14)$; [2 - 4 subsequent hooks] $45-50 / 12-13(40-65 / 12-19)$; [stoutest fifth or sixth hook] $30-40 / 17-21(36-50 / 18-$ 22); [3- 5 hooks posterior to stoutest hook] $27-30 / 7-9$ $(23-40 / 9-15)$; [last hook directed oblique] $26-28 / 8-9$ $(22-38 / 10-15)$. Proboscis receptacle $2.3-2.7$ (2.53.6) $\mathrm{mm} \times 230-300(250-380)$ wide at posterior end. 


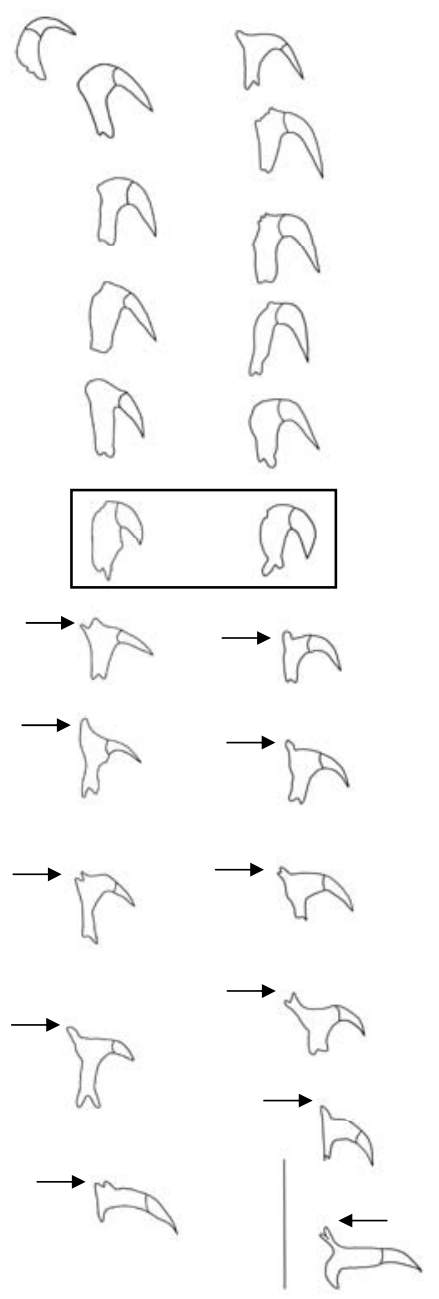

A
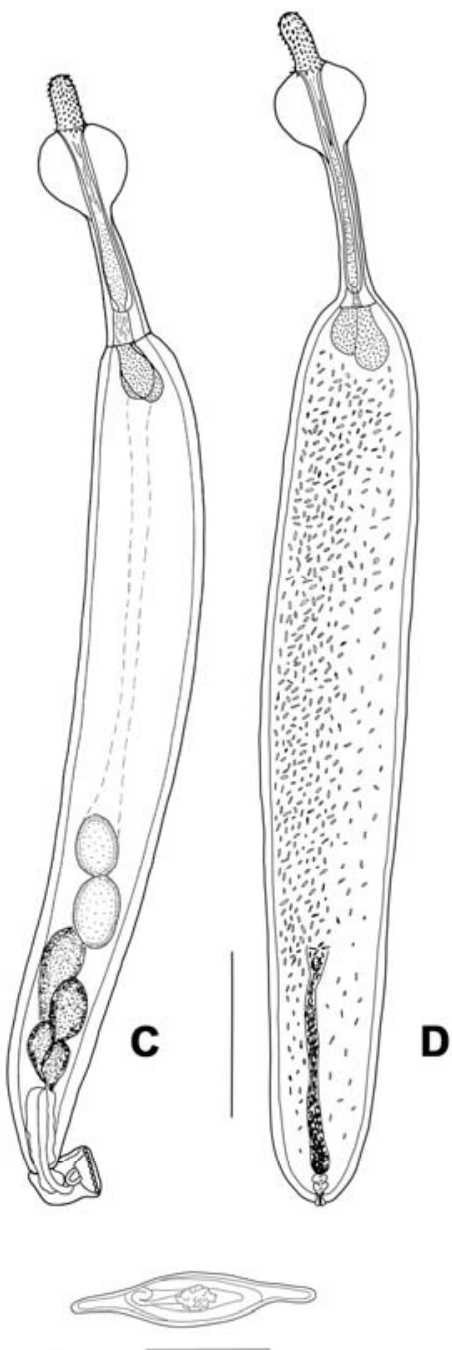

D

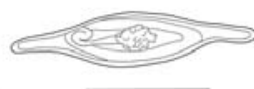

E

Fig. 4. Pomphorhynchus tereticollis. New material (ZMB Vermes Entozoa 7502) of adult males (A, C) and females (B, D, E). A, B - longitudinal row of proboscis hooks as visible in live specimens. Rectangle indicates the stoutest hooks No. 6, arrows indicate the proximal projections of bases of hooks Nos 7-11 (A) or 7-12 (B). Bar $=100 \mu \mathrm{m}$. C - male with atypical number of 4 cement glands and partially protruded copulatory bursa. Bar $=1 \mathrm{~mm} . \mathrm{D}-$ mature female, filled with eggs indicated schematically. Bar $=1 \mathrm{~mm} . \mathrm{E}-\mathrm{Egg}$. Bar $=50 \mu \mathrm{m}$.

Two lemnisci $90-710(540 / 900-1340 / 1430) \times 185-190$ $(110 / 160-480 / 540)$. Gonopore terminal (Fig. 4D). Numerous eggs and ovarian balls within trunk, eggs (95 - 126 $\times 12-23)$ (Fig. 4E)

\section{Taxonomic summary}

Type material

Type-host: Platichthys flessus (L.) (Pleuronectiformes, Pleuronectidae).

Type-locality: Baltic Sea near Greifswald (Gryphiae), probably Greifswalder Bodden $\left(54^{\circ} 13.22^{\prime} \mathrm{N} ; 13^{\circ} 32.48^{\prime} \mathrm{E}\right)$.

Date of collection: 25 October of unspecified year (before 1809).

Site of infection: intestine.

Helminth collection of Museum für Naturkunde Berlin (ZMB), originally catalogued under ZMB Vermes Entozoa 1226. Out of 56 syntypes, the male lectotype (ZMB Ver- mes Entozoa 1226) and one female paralectotype (ZMB Vermes Entozoa 7500a) were designated, figured and measured here. Measurements of six other paralectotypes are supplemented (ZMB Vermes Entozoa 7500b-g). The remaining 48 specimens are now catalogued under ZMB Vermes Entozoa 7501.

New material

Host: Platichthys flessus (L.) (Pleuronectiformes, Pleuronectidae).

Locality: Baltic Sea near Barhőft port $\left(54^{\circ} 26.10^{\prime} \mathrm{N}\right.$; $\left.13^{\circ} 02.00^{\prime} \mathrm{E}\right)$

Date of collection: 13 October 2006.

Site of infection: posterior intestine

Deposition of material: Helminth collection of the $\mathrm{Mu}-$ seum für Naturkunde Berlin (ZMB), ZMB Vermes Entozoa 7502.17 males and 14 females, all adult. 

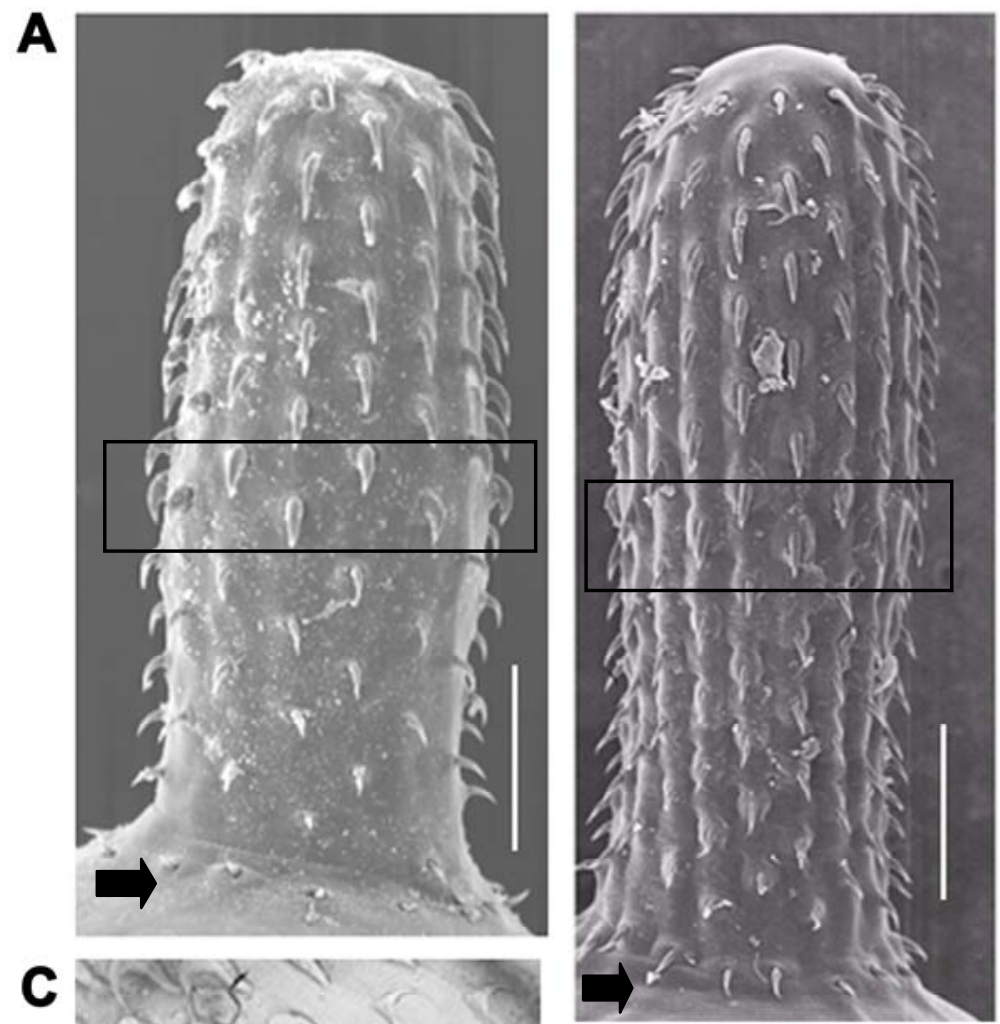

B
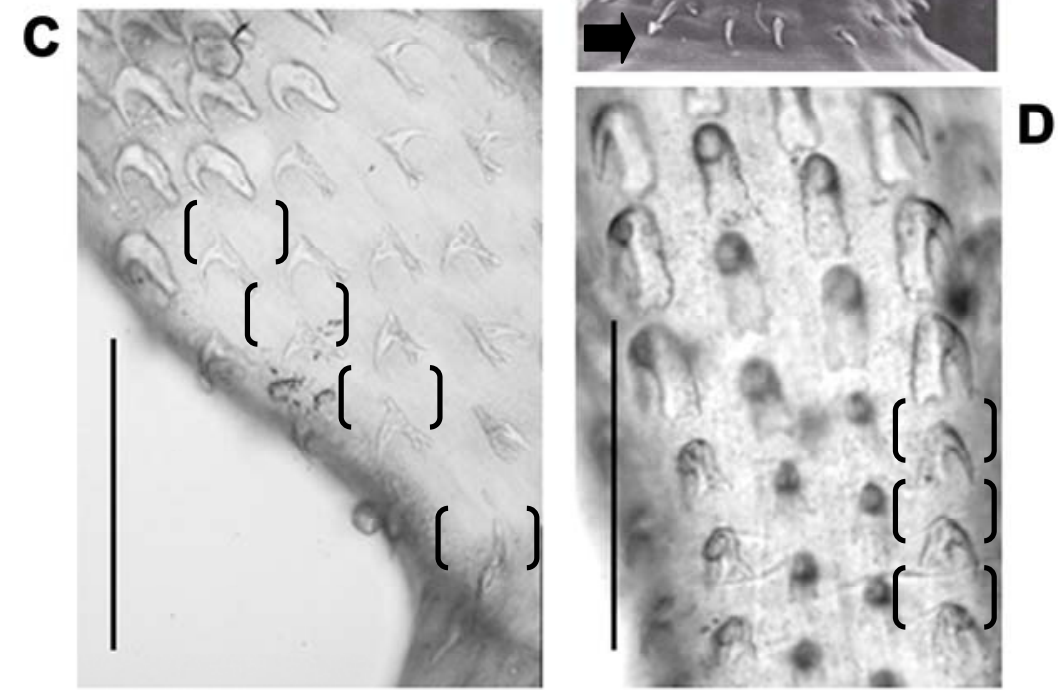

Fig. 5. Pomphorhynchus tereticollis - male from chub (Squalius cephalus) from the Olšava River, Slovakia (A, C) and Pomphorhynchus laevis female from chub from the Rokytná River, Czech Republic (B, D). Scanning electron micrographs of the proboscis (A, B); photomicrograph of the middle part of the proboscis of live specimen $(\mathrm{C}, \mathrm{D})$. Bars $=100 \mu \mathrm{m}$.

Rectangles indicate the proboscis area with the stoutest hooks Nos 5 and 6 (A) and without stoutest hooks (B); arrow indicates the last hooks located on the bulbus (A) and on the proboscis (B); brackets indicate the proximal part of bases of $7^{\text {th }}-10^{\text {th }}$ hooks armed with the projections $(\mathrm{C})$ and the proximal part of the base of $7^{\text {th }}-9^{\text {th }}$ hooks without any projections (D).

\section{Remarks}

Rudolphi (1809) listed Echinorhynchus tereticollis Rud. as the parasite of P. flessus (syn. Pleuronectes flessus) from Greifswald, and mentioned also the other fish hosts $M y$ oxocephalus scorpius (L.) (syn. Cottus scorpius), Lota lota (L.) (syn. Gadus lota), Zoarces viviparous (L.) (syn. Blennius viviparus), Anguilla anguilla (L.) (syn. Muraena anguilla), Gymnocephalus cernua (L.) (syn. Perca cernua), Perca fluviatilis L., various cyprinids, and Salmo trutta L. Later, Rudolphi (1819) enlarged the list of fish hosts by Acipenser sturio L., Silurus glanis L., Merlangius merlan- gus (L.) (syn. Gadus merlangus), Huso huso (L.) (syn. Accipenser huso), and Cottus gobio L. from Greifswald and Vienna. The only original Rudolphi's material is represented by a single set of 56 juvenile acanthocephalans from $P$. flessus from the vicinity of Greifswald (Gryphiae), and eight juvenile specimens were used for the redescription. As no adult specimens were among the type material, we collected new fresh material from type-host fish $P$. flessus caught in the Baltic Sea near Stralsund. Morphological characters of these acanthocephalans fit well with those of type specimens of $P$. tereticollis as well as with 
those of $P$. tereticollis described by Meyer (1932 - 1933). Later, additional three congeneric species have been described from European teleosts. Pomphorhynchus kostylevi Petrochenko, 1956, described from Capoeta capoeta sevangi DeFilippi (Cyprinidae), endemic to Lake Sevan (Armenia), is characterised by a relatively long proboscis $(940 \mu \mathrm{m})$ and large eggs $(126-129 \times 23 \mu \mathrm{m})$; Pomphorhynchus bosniacus Kiskároly et Čanković, 1967, described from Barbus barbus (L.) from the River Sava, possesses a small bulbus $(300-700 \mu \mathrm{m})$, long proboscis hooks $(42-61 \mu \mathrm{m})$ and small eggs $(83-95 \times 15-18 \mu \mathrm{m})$ (Petrochenko, 1956; Kiskároly \& Čanković, 1967). The latter species was reported from various other fishes (e.g. Salmo ohridanus Steindachner and Acipenser ruthenus L.) from lakes and rivers of the Balkan (Kakacheva-
Avramova, 1973; Hristovski et al., 1999; Cakić et al., 2008). The last European species, P. intermedius from Baltic $P$. flessus, closely resembles $P$. tereticollis and both species have been considered as synonyms of $P$. laevis by Amin et al. (2003).

Another Pomphorhynchus species, P. spindletruncatus Amin, Abdullah et Mhaisen, 2003, described from cyprinids Aspius vorax (Heckel) and Barbus xanthopterus (Heckel) from Northern Iran by Amin et al. (2003), has been recently reported also from six other cyprinid fishes and the marsh frog Pelophylax ridibundus (Pallas) (Ranidae) in the Asian part of Turkey (Heckmann et al., 2010). It differs from $P$. tereticollis by a ribbed proboscis surface, a wider $(3.6-4.1 \mathrm{~mm})$ and spindle-shaped trunk, a shorter proboscis $(520-750 \mu \mathrm{m})$, a longer $(167-232 \mu \mathrm{m})$ and

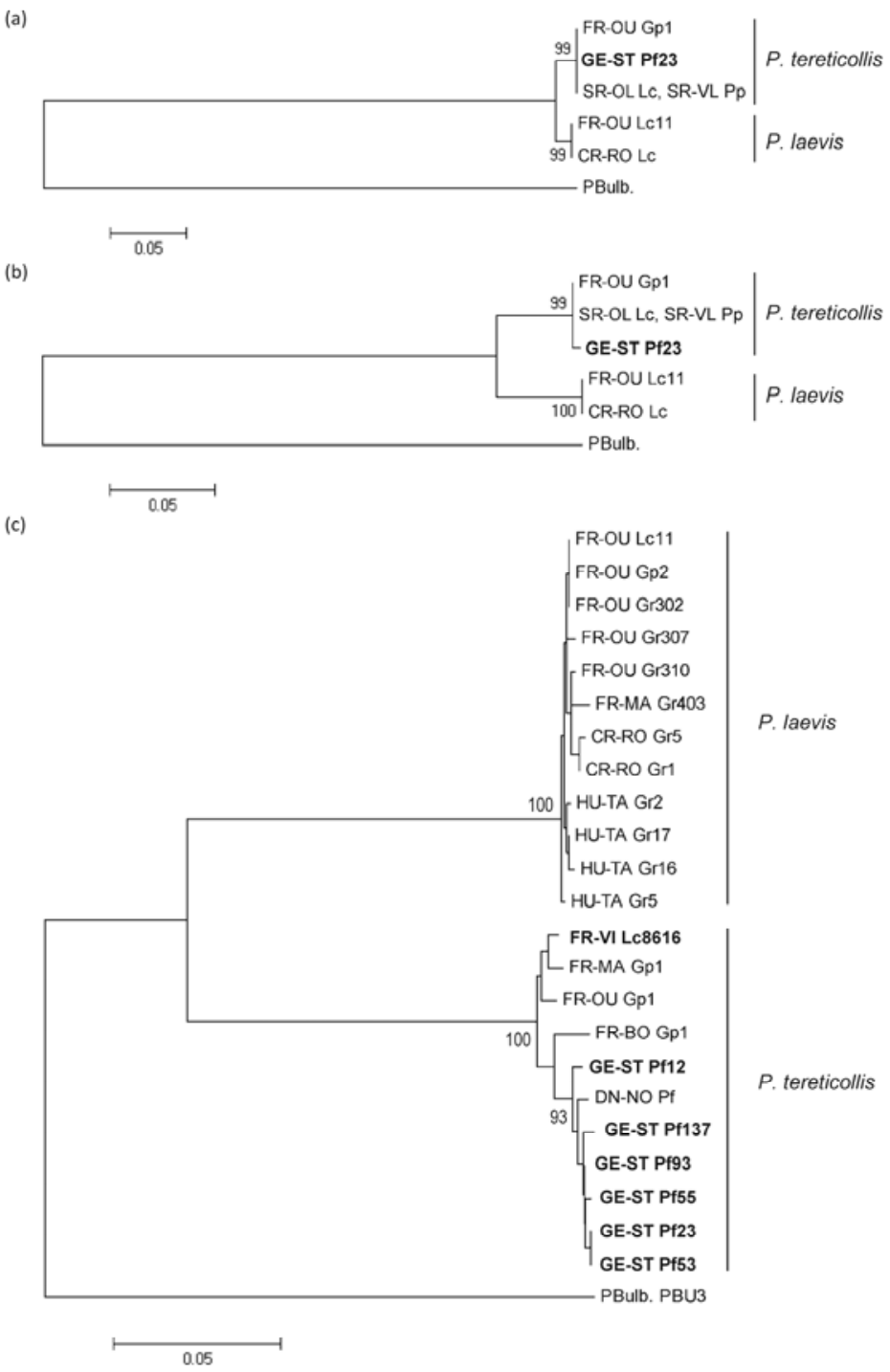

Fig. 6. Phylogenetic tree with maximum likelihood analysis displaying the relationships between Pomphorhynchus laevis and Pomphorhynchus tereticollis based on ITS1 (a), ITS2 (b) and partial COI (c) sequences. Labels refer to country of collection (CR, Czech Republic; DN, Denmark; FR, France; GE, Germany - near type locality; HU, Hungaria; SR, Slovak Republic) followed by the locality/river, and isolate (see Table 1 for abbreviations). Sequences in bold are new ones, while others were taken from the GenBank database. Bootstrap values are indicated. 
wider $(160-297 \mu \mathrm{m})$ bulb, a longer neck $(255-315 \mu \mathrm{m})$, and smaller eggs $(70-75 \times 11-15 \mu \mathrm{m})$ in egg-bearing females, and in larger testes $(670-142 \times 300-110 \mu \mathrm{m})$ in males (Heckmann et al., 2010). However, P. spindletruncatus possesses some characters similar to those of $P$. tereticollis, namely the posteriorly incomplete muscular wall of the proboscis receptacle, the occurrence of markedly stout (robust) hooks in the middle part of the proboscis, and the last hooks located at the posterior-most end of the proboscis (Amin et al., 2003; Heckmann et al., 2010).

\section{Molecular characterization}

Comparisons of sequences from the type host and near type locality to those already available in GenBank, were based on 257 - 283 bp fragments (ITS1), $272-277$ bp fragments (ITS2) and $610 \mathrm{bp}$ fragments (COI). Since Neighbor-Joining (NJ) analysis and Maximum Likelihood (ML) analysis gave the same bootstrap consensus tree topology, only the latter one is presented (Fig. 6). Levels of the genetic divergence and the tree topology reveal the clustering of $P$. laevis specimens in two groups (Table 2, Fig. 6). Stralsund isolates cluster with some $P$. laevis isolates from near the Baltic Sea (Northern Øresund, Denmark), and from freshwaters of France and Slovak Republic (see Table 1 for hosts and localities). Since the specimens from the type host and locality of $P$. tereticollis, which are morphologically identical with paratypes of this species, are genetically closely related with some $P$. laevis specimens, the latter isolates are considered to be conspecific with $P$. tereticollis. This cluster of $P$. tereticollis sequences shares fixed differences compared to the other $P$. laevis sequences, in particular several deletions in the ITS1 region. This size polymorphism of ITS1 can be considered as diagnostic character, being based on sequences from 56 more individuals (data not shown). The whole ITS1 gene can be amplified for molecular discrimination of $P$. tereticollis and $P$. laevis by a simple PCR assay, with the BD1 forward primer (5'GTCGTAACAAGGTTTCCGTA3') (Králová-Hromadová et al., 2003), and a reverse primer designed in a conserved 3 ' region of the 5.8S rRNA (AC/ITS1r : 5'TTGCGAGCCAAGTGATTCAC3'), at $50^{\circ} \mathrm{C}$ annealing temperature. The amplification products from $P$. tereticollis and $P$. laevis specimens can be visualized in a $2 \%$ agarose gel at about 350 bp and 320 bp respectively (Franceschi et al., 2008).

\section{Discussion}

The present results have demonstrated the morphological congruence between the type specimens of $P$. tereticollis and worms from the same host species and region. All acanthocephalans possess the last hooks localised at the anterior part of the bulbus or rarely at the posterior-most end of the proboscis and hooks Nos. 5 or 6 are markedly stout (robust), thus being distinct from surrounding hooks. The worms also share a similar size of their body parts, genital organs and proboscis hooks (type juveniles are smaller due to their developmental stage). These facts suggest that the flounder parasites from the Baltic coast near Stralsund belong to $P$. tereticollis.

The most important species-specific feature of $P$. tereticollis is the existence of proximal projections of the basal parts of the proboscis hooks located on the posterior proboscis half, well visible in the newly collected specimens (Figs. 4, 5). This morphological character was also used by Meyer $(1932-1933)$ to distinguish $P$. tereticollis from $P$. laevis, which has no proximal protrusions of bases of relevant hooks. This trait characterizing $P$. tereticollis, however, varied in size and shape among worms parasitizing individual fish, and some specimens possessed the projections of hook bases less developed, i.e. identical to those of $P$. intermedius as shown by Engelbrecht (1957). Therefore, the latter species is considered to be a synonym of $P$. tereticollis.

Due to the fact that the most important differential feature the shape of the hook bases - is visible only in live worms and due to the overall similarity of $P$. laevis and $P$. tereticollis, all acanthocephalans found in freshwater and brackish fishes throughout the Palaearctic region were considered to be the former species for a long time (e.g. Moravec \& Scholz, 1991; Chibani et al., 2004; Kennedy, 2006). However, the present data allows us to confirm the

Table 2. Sequence similarity of Pomphorhynchus isolates (see Table 1), given as percentage nucleotide identity. Length of compared fragments: $257-283$ bp of ITS1, $272-277$ bp of ITS2, and 610 bp of COI. Specimens of $P$. tereticollis misidentified as $P$. laevis are labelled with an asterisk.

\begin{tabular}{lccc}
\hline & \multicolumn{3}{c}{ Range of sequence similarity in \% (sample size) } \\
Pomphorhynchus sample & ITS1 & ITS2 & COI \\
\hline P. tereticollis Germany & $100(4)$ & $100(4)$ & $99.1-100(6)$ \\
P. tereticollis Germany / P. laevis $*$ France & $100(4 / 1)$ & $99.6(4 / 1)$ & $97.6-98.3(6 / 4)$ \\
P. tereticollis Germany / P. laevis $*$ Slovakia & $100(4 / 1)$ & $99.6(4 / 1)$ & - \\
P. tereticollis Germany / P. laevis $*$ Denmark & - & - & $99.0-99.5(6 / 1)$ \\
P. tereticollis Germany / P. laevis France & $88.6(4 / 1)$ & $90.9(4 / 1)$ & $80.0-80.7(6 / 6)$ \\
P. tereticollis Germany / P. laevis Czech Republic & $88.6(4 / 1)$ & $90.9(4 / 1)$ & $79.9-80.4(6 / 2)$ \\
P. tereticollis Germany / P. laevis Hungary & - & - & $80.2-80.7(6 / 4)$ \\
\hline
\end{tabular}


occurrence of both $P$. laevis and $P$. tereticollis in several freshwater fishes, amphipod intermediate hosts, and fluvial localities. New Pomphorhynchus specimens from flounder, which are morphologically identical with the type material of $P$. tereticollis, are genetically closely related (almost identical) with previously identified $P$. laevis specimens from freshwater chub Squalius cephalus (L.), minnow Phoxinus phoxinus (L.), and Gammarus pulex (L.) from France and Slovakia, and from flounder in Northern Øresund, Denmark (Køie, 1999; Køie, pers. comm.). Therefore, the latter isolates are considered to be conspecific with $P$. tereticollis. This means that $P$. tereticollis parasitizing flounder and fluvial hosts represent a single morphologically and genetically homogeneous group occurring throughout Europe, together with its more common congener $P$. laevis. In some localities, e.g. in the Rivers Ouche and Tille, France, they can occur sympatrically also in barbel Barbus barbus (L.) (Perrot-Minnot, unpublished results).

The resurrection of $P$. tereticollis as a species distinct from $P$. laevis calls for a complete re-evaluation of their respective biogeography and ecology. A phylogeographic study including the geographic distribution of several lineages of $P$. laevis and $P$. tereticollis throughout Europe is currently in progress. Ecological studies addressing the range of hosts used by $P$. laevis and $P$. tereticollis in the local community where they occur in sympatry should also be conducted. More generally, our study also illustrates taxonomic difficulties in studies on acanthocephalans (a 'systematist's nightmare'; Kennedy, 2006) as they have low anatomical diversity but can exhibit a rather considerable intraspecific variation in the only hard structures they possess, the hooks on their proboscis (Kennedy, 2006). Coupling morphological and genetic studies is therefore necessary to clarify the taxonomic status of other suspected cases of cryptic species, such as Echinorhynchus gadi Zoega in Müller, 1776 and Leptorhynchoides thecatus (Linton, 1981) (Wayland et al., 2005; Steinauer et al., 2006).

\section{Acknowledgements}

We thank to Dr. Götz B. Reinicke, Deutsches Meeresmuseum, Stralsund, Germany, for providing fresh flounders from waters of the Baltic Sea near Stralsund and kind help in providing necessary information. We are indebted to an anonymous referee for valuable comments. Our thanks are due to M. Borovková, B. Škoříková (both the Institute of Parasitology, BC AS CR in České Budějovice, Czech Republic) and Dr. Z. Vasilková (Institute of Parasitology SAS, Košice, Slovakia) for their kind help in processing drawings and plates. We also wish to thank Dr. Omar Amin for a stimulating discussion on acanthocephalan systematics. This study was supported by the European Union-funded Integrated Activities grant SYNTHESYS (DE-TAF-2337) to M. Š. and a Plan d'actions intégrées (PAI) Štefánik No. 12 to the two first authors.

The publication has been realized within a frame of the project Centre of Excellence for Parasitology (Code ITMS: 26220120022) based on the support of the Operational Programme "Research \& Development" funded from the European Regional Development Fund (rate 0.4).

\section{References}

Amin, O. M., AbDullah, S. M. A., Mhaisen, F. T. (2003): Description of Pomphorhynchus spindletruncatus n. sp. (Acanthocephala: Pomphorhynchidae) from freshwater fishes in northern Iraq, with the erection of a new pomphorhynchid genus, Pyriproboscis n. g., and keys to the genera of the Pomphorhynchidae and the species of Pomphorhynchus Monticelli, 1905. Syst. Parasitol., 54: 229 - 235

Bombarová, M., Marec, F., NGuyen, P., ŠPakulová, M. (2007): Divergent location of ribosomal genes in chromosomes of fish thorny-headed worms, Pomphorhynchus laevis and Pomphorhynchus tereticollis (Acanthocephala). Genetica, 131: 141 - 149

BROWN, A. F. (1987): Anatomical variability and secondary sexual characteristics in Pomphorhynchus laevis (Müller, 1776) (Acanthocephala). Syst. Parasitol., 9: 213 - 219

CAKIĆ, P.D., DJIKANOVIĆ, V. DJ., KULIŠIĆ, Z. B., PAUNOVIĆ, M. M., JaKovČEV-Todorović, D. G., MilošEvić, S. M. (2008): The fauna of endoparasites in Acipenser ruthenus Linnaeus, 1758 from the Serbian part of the Danube River. Arch. Biol. Sci., Belgrade, 60: 103 - 107

Chibani, M., Glazewska, I., Rokicki, J. (2004): The use of isozymes to identify specimens of Pomphorhynchus (Acanthocephala) in flounder, Platichthys flesus from the Baltic Sea. J. Mar. Biol. Assoc.U.K., 84: 277 - 297

DUDIŇÁK, V., ŠNÁBEL, V. (2001): Comparative analysis of Slovak and Czech populations of Pomphorhynchus laevis (Acanthocephala) using morphological and isoenzyme analyses. Acta Zool. Univ. Comen., 44: 41 - 50

Engelbrecht, H. (1957): Einige Bemerkungen zu Pomphorhynchus laevis (Zoega, Müller 1776) als Parasit in Pleuronectes flesus und Pleuronectes platessa, Zbl. Bakteriol. Parasitenkd. Infekt. Hyg., 168: 474 - 479

Franceschi, N., BAuer, A., Bollache, L. Rigaud, T. (2008): The effects of parasite age and intensity on variability in acanthocephalan-induced behavioural manipulation. Int. J. Parasitol., 40: $1161-117$

Giribet, G., Sørensen, M. V., Funch, P., Kristensen, R. M., STERrER, W. (2004): Investigations into the phylogenetic position of Micrognathozoa using four molecular loci. Cladistics, 20: 1 - 13

Golvan, Y. J. (1969) Systématique des acanthocéphales (Acanthocephala Rudolphi 1801). Première partie. L'ordre des Palaeacanthocephala Meyer 1931. Premier fascicule. La super-famille des Echinorhynchoidea (Cobbold 1876) Golvan et Houin 1963. Mem. Mus. Hist. Nat. (Paris), Sér. A, Zool, nouvelle série, 57: $1-373$

GuILlÉN-HernÁNDEZ, S., WhitFiEld, P. J. (2001): A comparison of freshwater and marine/estuarine strains of Pomphorhynchus laevis occurring sympatrically in flounder, Platichthys flessus, in the tidal Thames. J. Helminthol., 75: $237-243$ 
HALl, T. A. (1999). BioEdit: a user-friendly biological sequence alignment editor and analysis program for Windows 95/98/NT. Nucl. Acids Symp. Series, 41: 95 - 98

Hartwich, G., Kilias, I., Neuhaus, B. (1998): Die Acanthocephalen-Typen des Museums für Naturkunde in Berlin. Mitt. Mus. Nat. Kd. Berl., Zool. Reihe, 74: 249 - 258 Heckmann, R. A., Oguz, M. C., Amin, O. M., Düsen, S., TEPE, Y., Aslan, B. (2010): Host and geographical distribution of Pomphorhynchus spindletruncatus (Acanthocephala: Pomphorhynchidae) in Turkey, with enhanced descriptions from new fish and amphibian hosts using SEM, and histopathological note. Sci. Parasitol., 11: 129 - 139

Hristovski, N., Stojanovski, S., Kulišić, Z., CAKIĆ, P., HRISTOVSKI, M. (1999): Parasitofauna of the Ohrid belvica (Acantholingua ohridana Hadžišče, 1961) from lake Ohrid (Macedonia). Acta Vet. Fac. Vet. Med. Beograd, 49:91 104

KaKACHEVA-AVRAmOVA, D. (1973): The helminth fauna of fishes in the rivers from the Central and Eastern part of Balkan Mountains. Izv. Tsentr. Khelminthol. Lab. 16: 87 - 110

Kennedy, C. R. (1984): The status of flounders, Platichthys flessus (L.) as hosts of the acanthocephalan Pomphorhynchus laevis (Müller) and its survival in marine conditions. J. Fish Biol. 24: 135 - 149

KENNEDY, C. R. (2006): Ecology of Acanthocephala. Cambridge, UK, Cambridge University Press, 249 pp.

Kennedy, C. R., Broughton, P. E., Hine, P. M. (1978): The status of brown and rainbow trout, Salmo trutta and $S$. gairdneri as hosts of the acanthocephalan Pomphorhynchus laevis. J. Fish Biol., 13: 265 - 275

KISKÁroly, M., ČANKOVIĆ, M. (1967): Pomphorhynchus bosniacus nov. sp. aus Barben Barbus barbus (L.) des Save-Gebietes. Zool. Anz., 182: 69 - 74

KøIE, M. (1999): Metazoan parasites of flounder Platichthys flesus (L.) along a transect from the southwestern to the northeastern Baltic Sea. ICES J. Mar. Sci., 56: 157 - 163

KrÁlová-Hromadová, I., TIETz, D.F., Shinn, A.P., ŠPAKUlOVÁ, M. (2003): ITS rDNA sequences of Pomphorhynchus laevis (Zoega in Müller, 1776) and P. lucyi Williams and Rogers, 1984 (Acanthocephala: Palaeacanthocephala). Syst. Parasitol., 56: 141 - 145
Meyer, A. (1932-1933): Acanthocephala. In: Dr. H. G. Bronn's Klassen und Ordnungen des Tier-Reichs, Band 4, Abt. 2, Lief. 1, Leipzig, Akademische Verlagsgesellschaft: 1 - 332 pp.; Lief 2, Leipzig, Akademische Verlagsgesellschaft: $333-582$ pp.

Moravec, F., Scholz, T. (1991): Observations on the biology of Pomphorhynchus laevis (Zoega in Müller, 1776) (Acanthocephala) in the Rokytná River, Czech and Slovak Federative Republic. Helminthologia, 28: 23 - 29

Moret, Y., Bollache, L., Wattier, R., Rigaud, T. (2007): Is the host or the parasite the most locally adapted in an amphipod-acanthocephalan relationship? A case study in a biological invasion context. Int. J. Parasitol., 37: 637-644 O’Mahony, E. M., Kennedy, C. R., Holland, C. V. (2004): Comparison of morphological characters in Irish and English populations of the acanthocephalan Pomphorhynchus laevis (Müller, 1776). Syst. Parasitol., 59: 147 - 157

PERROT-MinNOT, M.-J. (2004): Larval morphology, genetic divergence, and contrasting levels of host manipulation between forms of Pomphorhynchus laevis (Acanthocephala). Int. J. Parasitol., 34: 45 - 54

PetrochenKo, V. I. (1956): Acanthocephala of domestic and wild animals. Moscow: Izdatel'stvo Akademii Nauk SSSR, Vol. 1: 431 pp. (In Russian)

RUDOLPHI, C. A. (1809): Entozoorum sive vermium intestinalium Historia naturalis, Vol. 2, Part 1. $8^{\circ}$, Amstelaedami. $457 \mathrm{pp}$.

RUDOLPHI, C. A. (1819): Entozoorum synopsis, cui accedunt mantissa duplex et indices locupletissimi. Cum tab. III aeneis. Berolini. 811 pp.

Steinauer, M. A., NiCKOL, B. B., ORTI, G. (2007). Cryptic speciation and patterns of phenotypic variation of a highly variable acanthocephalan parasite. Mol. Ecol., 16: 4097 4109

WAYLAND M. T. (2010): Proboscis profiler: a tool for detecting acanthocephalan morphotypes. Syst. Parasitol., 76: $159-167$

Wayland, M. T., Gibson, D., Sommerville, C. (2005). Morphometric discrimination of two allozymically diagnosed sibling species of the Echinorhynchus gadi Zoega in Müller complex (Acanthocephala) in the North Sea. Syst. Parasitol. 60: 139 - 149 